\title{
Kemampuan representasi matematis ditinjau dari self efficacy siswa kelas VIII tahun ajaran 2020/2021
}

\author{
Retno Saputri Said ${ }^{1}$, Sri Subarinah ${ }^{2}$, Baidowi ${ }^{3}$, Sripatmi ${ }^{4}$ \\ ${ }^{1}$ Mahasiswa Prodi Pendidikan Matematika, FKIP Universitas Mataram \\ 2,3,4 Dosen Prodi Pendidikan Matematika, FKIP Universitas Mataram \\ Email: retnosernaru@gmail.com
}

Diterima:20-09-2021; Direvisi:26-09-2021; Dipublikasi:30-09-2021

\begin{abstract}
This study aimed to describe the mathematical representation ability in terms of self-efficacy students of grade VIII in academic year 2020/2021. The research method used was descriptive research with qualitative approach. The instruments used in this study were self-efficacy questionnaires, mathematical representation ability tests and interview guides. The research subjects were 31 students of grade VIII E with 22 students having high self-efficacy and 9 students having low self-efficacy. Then 3 students from each category of self-efficacy were selected to be given a test and an interview. Based on the results, the mathematical representation abilities of students who have high self-efficacy are able to present a mathematical problem in the form of images or diagrams, solve mathematical problems using mathematical equations or models and sufficiently able to use written words in solving mathematical problems. Meanwhile, the mathematical representation abilities of students who have low self-efficacy are able to present a mathematical problem in the form of a picture or diagram, solve mathematical problems using mathematical equations or models but less able to use written words in solving mathematical problems.
\end{abstract}

Keywords: Mathematical Representation Ability, Self Efficacy

\begin{abstract}
Abstrak
Penelitian ini bertujuan untuk mendeskripsikan kemampuan representasi matematis ditinjau dari self efficacy pada siswa kelas VIII tahun ajaran 2020/2021. Metode penelitian yang digunakan adalah penelitian deskriptif dengan pendekatan kualitatif. Instrumen yang digunakan dalam penelitian ini adalah angket self efficacy, tes kemampuan representasi matematis dan pedoman wawancara. Subjek penelitiannya 31 siswa kelas VIII E dengan 22 siswa memiliki self efficacy tinggi dan self efficacy rendah sebanyak 9 siswa. Dari setiap kategori self efficacy dipilih 3 siswa untuk diberikan tes dan diwawancara. Hasilnya adalah kemampuan representasi matematis siswa dengan self efficacy tinggi mampu menyajikan suatu masalah matematika kedalam bentuk gambar atau diagram, mampu menyelesaikan masalah matematika menggunakan persamaan atau model matematika dan mampu menggunakan kata-kata tertulis dalam menyelesaikan masalah matematika. Sedangkan kemampuan representasi matematis siswa dengan self efficacy rendah mampu menyajikan suatu masalah matematika kedalam bentuk gambar atau diagram, mampu menyelesaikan masalah matematika menggunakan persamaan atau model matematika dan kurang mampu menggunakan kata-kata tertulis dalam menyelesaikan masalah matematika.

Kata kunci: Kemampuan Representasi Matematis, Self Efficacy
\end{abstract}

\section{PENDAHULUAN}

Matematika merupakan salah satu bidang studi yang dipelajari siswa pada semua tingkat pendidikan baik dari pendidikan dasar, menengah maupun pendidikan tinggi. Tujuan mata pelajaran matematika pada Sekolah Menengah Pertama dalam Peraturan Menteri Pendidikan Nasional RI No.22 Tahun 2006 yaitu diantaranya 
mengkomunikasikan gagasan dengan simbol, tabel, diagram, atau media lain untuk memperjelas keadaan atau masalah (Depdiknas, 2006). Dalam menunjang ketercapaian tujuan pembelajaran tersebut, diperlukan kemampuan matematis dalam membantu proses belajar siswa.

Terdapat lima standar proses yang perlu dimiliki siswa yaitu kemampuan pemecahan masalah, penalaran dan pembuktian, komunikasi, koneksi dan representasi. Representasi merupakan pusat dalam proses pembelajaran matematika (NCTM, 2000). Jones dan Knuth menuturkan bahwa representasi merupakan cara atau bentuk pengganti dalam menyajikan suatu masalah dalam bentuk objek, gambar, kata-kata, atau simbol matematika (Sabirin, 2014). Kemampuan representasi matematis diperlukan siswa untuk menemukan dan membuat cara berpikir siswa dalam mengkomunikasikan gagasan matematis yang sifatnya abstrak menuju konkret agar lebih mudah dipahami (Efendi, 2012). Namun pada kenyataannya tidak semua siswa memiliki kemampuan representasi matematis yang baik.

Dari hasil wawancara dengan salah seorang guru mata pelajaran matematika SMP Negeri 6 Mataram diketahui bahwa kemampuan representasi siswa masih kurang, untuk setiap kelasnya hanya beberapa siswa yang memiliki kemampuan representasi tinggi. Hal ini ditunjukkan dengan siswa masih kurang dalam hal mengubah permasalahan matematika ke dalam model matematika dan mengalami kesulitan dalam mengkomunikasikan gagasan matematis.. Salah satu penyebab rendahnya kemampuan representasi matematis siswa yaitu kurangnya perhatian siswa saat proses pembelajaran berlangsung. Beberapa siswa cenderung putus asa saat menemukan kesulitan dalam memahami materi maupun memecahkan masalah matematika sehingga lebih memilih mengalihkan perhatian ke hal lain. Seseorang yang memiliki self efficacy rendah cenderung akan menyerah atau berputus asa ketika upaya awal mereka untuk mendapatkan solusi gagal, mudah khawatir, cemas dan merasa takut (Bandura, 1997).

Dalam menghadapi suatu masalah siswa akan mengerjakannya sesuai anggapannya, jika dirasa sulit maka siswa cenderung akan menghindarinya, begitu sebaliknya jika dirasa mudah masalah tersebut akan diselesaikan dan menganggap masalah tersebut bagian dari tantangan. Self efficacy adalah keyakinan seseorang akan kemampuan dirinya untuk mengatur dan melaksanakan tindakan untuk mencapai tujuan dan hasil tertentu (Bandura, 1997). Self efficacy memiliki hubungan yang signifikan sehingga dapat memberikan kontribusi positif terhadap pencapaian kemampuan matematis siswa (Efendi, 2012). Self efficacy yang kuat atau tinggi sangat dibutuhkan siswa dalam menyelesaikan masalah matematika sehingga dapat mencapai keberhasilan dalam pembelajaran tersebut (Subaidi, 2016).

Berdasarkan uraian di atas, tujuan penelitian ini adalah untuk mendeskripsikan kemampuan representasi matematis ditinjau dari self efficacy siswa kelas VIII tahun ajaran 2020/2021. Penelitian ini diharapkan dapat menyediakan informasi serta bekal 
pengetahuan bagi siswa dalam meningkatkan kemampuan representasinya dalam setiap proses belajar. Bagi guru, sebagai bahan masukan untuk menumbuhkan self efficacy siswa dalam tiap pembelajaran agar mampu mendorong proses kemampuan representasi matematis siswa. Bagi peneliti, dapat menambah wawasan mengenai kemampuan representasi dan menjadi sumber pengetahuan untuk melakukan penelitian yang lebih inovatif.

\section{METODE PENELITIAN}

Metode penelitian yang digunakan pada penelitian ini adalah penelitian deskriptif dengan pendekatan kualitatif. Pada penelitian ini prosedur pemecahan masalahnya dengan cara menggambarkan objek penelitian pada saat keadaan sekarang berdasarkan fakta-fakta sebagaimana adanya. Pendekatan kualitatif menekankan pada makna, penalaran, definisi suatu situasi tertentu dan aspek pendalaman data demi mendapat kualitas hasil penelitian (Siregar, 2016).

Subjek dalam penelitian ini adalah kelas VIII E berdasarkan rekomendasi dan pertimbangan guru matematika kelas VIII. Pertimbangan dalam hal ini juga, subjek penelitian terbatas pada siswa yang bisa online dan mendapatkan izin dari orang tua untuk ke sekolah. Langkah awal dalam pemilihan subjek penelitian adalah dengan memberikan angket self efficacy kepada kelas VIII E. Sehingga, subjek penelitian ini adalah siswa yang telah mengisi angket self efficacy melalui google form kemudian dipilih 6 orang siswa berdasarkan kategori self efficacy untuk diberikan tes dan diwawancara. Subjek terdiri dari 6 orang siswa yang mewakili tingkatan self efficacy dimana masing-masing 3 siswa mewakili self efficacy tinggi dan 3 siswa self efficacy rendah.

Teknik pengumpulan data yang digunakan adalah angket, tes dan wawancara. Instrumen yang digunakan dalam penelitian ini yaitu menggunakan angket self efficacy, tes kemampuan representasi matematis dan pedoman wawancara. Angket digunakan untuk mengukur tingkat self efficacy yang dimiliki siswa. Indikator yang digunakan dalam angket ini merupakan indikator dalam dimensi-dimensi self efficacy, selanjutnya disusun menjadi 28 pernyataan. Tes yang dimaksudkan berupa 3 soal uraian materi segi empat dan penyajian data yang menghasilkan data hasil tes kemampuan representasi matematis siswa berdasarkan indikator representasi matematis. Indikator kemampuan representasi yang digunakan mengacu pada aspek representasi menurut Villegas (2009) seperti pada Tabel 1. 
Tabel 1 Indikator Kemampuan Representasi Matematis

\begin{tabular}{|c|c|}
\hline Aspek representasi & Indikator \\
\hline Representasi verbal & $\begin{array}{l}\text { Menggunakan kata-kata tertulis dalam } \\
\text { menyelesaikan masalah matematika }\end{array}$ \\
\hline Representasi gambar & $\begin{array}{l}\text { Menyajikan suatu masalah matematika ke } \\
\text { dalam bentuk gambar atau diagram }\end{array}$ \\
\hline Representasi simbol & 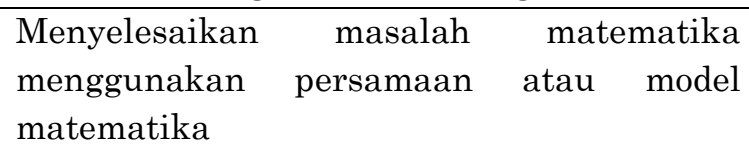 \\
\hline
\end{tabular}

Wawancara dilakukan untuk memperjelas dan menggali informasi yang belum tampak dari hasil tes subjek penelitian. Wawancara dilakukan dengan menanyakan serentetan pertanyaan, kemudian diperdalam untuk memperjelas dan memperoleh keterangan lebih lengkap.

Sebelum digunakan dalam penelitian, intrumen penelitian terlebih dahulu diuji validitas dengan menggunakan analisis validitas isi. Pengujian validitas isi dapat dibantu dengan menggunakan kisi-kisi instrumen kemudian dikonsultasikan dengan ahli. Hasil pendapat ahli terhadap instrumen melalui lembar validasi kemudian dihitung dan dianalisis menggunakan koefisien $V$ Aiken .

Analisis data merupakan proses mencari dan menyusun secara sistematis data yang diperoleh dari hasil angket, hasil tes, hasil wawancara agar dapat disimpulkan. Pada penelitian ini teknik analisis data yang digunakan merujuk pada Model Miles dan Huberman. Ada tiga langkah pengolahan data kualitatif yakni reduksi data, penyajian data dan penarikan kesimpulan. Selanjutnya, perhitungan untuk mengetahui persentase kemampuan representasi matematis siswa dari skor hasil jawaban tes berdasarkan pada pedoman penskoran yang digunakan, dapat menggunakan rumus berikut (Padila at.al, 2020).

$$
\text { Persentase skor }=\frac{\text { Skor yang diperoleh }}{\text { Jumlah skor maksimal }} \times 100 \%
$$

Untuk mengetahui kategori persentase skor yang diperoleh siswa dapat dilihat pada Tabel 2 berikut (Arikunto, 2018).

Tabel 2 Tingkat Persentase Skor Jawaban Siswa

\begin{tabular}{cc}
\hline Persentase Skor (\%) & Kategori \\
\hline $80 \leq P \leq 100$ & Sangat Baik \\
$60 \leq P<80$ & Baik \\
$40 \leq P<60$ & Cukup \\
$20 \leq P<40$ & Kurang \\
$0 \leq P<20$ & Sangat Kurang \\
\hline
\end{tabular}




\section{HASIL DAN PEMBAHASAN}

Pengujian validitas instrumen angket self efficacy, tes kemampuan representasi matematis dan pedoman wawancara dilakukan oleh dua orang ahli yaitu dosen Pendidikan Matematika Universitas Mataram. Dari hasil perhitungan Aikent diperoleh untuk validitas angket self efficacy dan tes kemampuan representasi matematis dikategorikan valid dan layak digunakan tanpa perbaikan. Sedangkan untuk instrumen pedoman wawancara dari hasil penilaian ahli yang kemudian dianalisis dengan validitas Aikent berada pada kategori cukup valid dan instrumen layak digunakan dengan sedikit perbaikan.

Data yang diperoleh dalam penelitian ini berupa hasil angket, tes dan wawancara dari siswa. Angket self efficacy siswa dibagikan pada kelas VIII E, sebanyak 31 siswa mengisi angket self efficacy melalui google form. Selanjutnya, self efficacy dikelompokkan dalam dua kategori yaitu self efficacy tinggi dan self efficacy rendah. Berdasarkan data skor hasil angket self efficacy siswa diperoleh hasil dimana kategori self efficacy tinggi ada 22 siswa dan 9 siswa berada pada kategori self efficacy rendah. Kemudian, dari hasil pengkategorian self efficacy dipilih 6 siswa untuk mewakili tiap tingkatan self efficacy dimana 3 siswa mewakili self efficacy tinggi dan 3 siswa self efficacy rendah. Selanjutnya 6 orang tersebut diberikan tes soal kemampuan representasi dan diwawancara dimana $\mathrm{S}_{1}, \mathrm{~S}_{2}$ dan $\mathrm{S}_{3}$ mewakili self efficacy tinggi dan $\mathrm{S}_{4}, \mathrm{~S}_{5}$ dan $\mathrm{S}_{6}$ mewakili siswa self efficacy rendah. Berdasarkan hasil tes dan wawancara diperoleh sebagai berikut.

\subsection{Hasil Kemampuan Representasi Matematis Siswa Self Efficacy Tinggi}

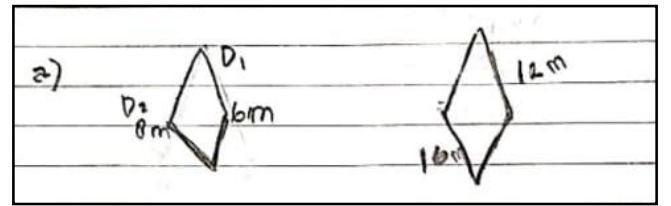

Gambar 1 Hasil pekerjaan $S_{1}$ soal representasi gambar

Berdasarkan hasil pekerjaan $\mathbf{S}_{1}$ pada Gambar 1, dapat dilihat $\mathrm{S}_{1}$ mampu menggambar belah ketupat namun masih salah dalam pemahaman konsep mengenai diagonal belah ketupat dalam penempatan diagonal, sehingga keterangan yang diberikan salah. Setelah diadakan wawancara lanjutan $\mathrm{S}_{1}$ dapat menjelaskan serta menunjukkan bahwa sisi dan diagonal merupakan dua hal berbeda. Sehingga, $\mathrm{S}_{1}$ dapat menggambar belah ketupat dengan benar sesuai dengan yang ditanyakan dalam soal.

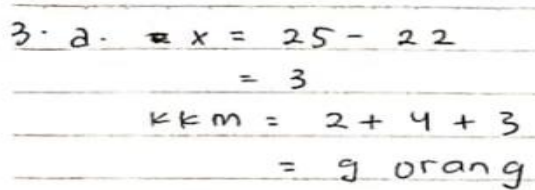

Gambar 2 Hasil pekerjaan $\mathrm{S}_{3}$ soal representasi simbol

Adapun ringkasan wawancara dengan $\mathrm{S}_{3}$ untuk soal nomor 3 a sebagai berikut

$\mathrm{P} \quad$ : "Untuk soal nomor 1a apa yang ditanya" 
$\mathrm{S}_{3} \quad$ : "Banyak siswa yang mendapat nilai dibawah KKM, KKM metematika adalah 7. Dihitung banyak siswa, $x$ sama dengan banyak siswa $25-22=3$, maka nilai dibawah KKM nya nilai 6,5 , dan 4 , ada $2+4+3=9$ orang"

Berdasarkan Gambar 2 dan hasil wawancara dapat dilihat bahwa $\mathrm{S}_{3}$ memahami maksud soal dan melakukan penyelesaian dengan benar. Persamaan matematika dituliskan dengan benar. $S_{3}$ mampu membuat perencanaan dan menjelaskan jawaban yang ditulis dengan sistematis.

$$
\text { C. Jodi, Lucsnye lebih besar setelah diperfonjong }
$$

\section{Gambar 3 Hasil pekerjaan $\mathrm{S}_{2}$ soal representasi verbal}

Dari Gambar $3 \mathrm{~S}_{2}$ menuliskan jawaban yang sesuai dengan soal, bahwa luas belah ketupat lebih besar atau bertambah setelah diagonalnya diperpanjang. Jawaban yang diberikan cukup masuk akal. Namun jawaban yang ditulis kurang lengkap dan kurang sistematis.

\subsection{Hasil Kemampuan Representasi Matematis Siswa Self Efficacy Rendah}

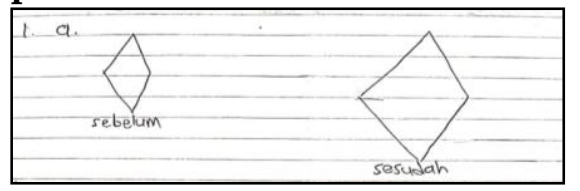

Gambar 4 Hasil pekerjaan $\mathbf{S}_{\mathbf{5}}$ soal representasi gambar

Berdasarkan Gambar 4 terlihat $\mathrm{S}_{5}$ dapat menggambar belah ketupat sebelum dan sesudah diagonal diperpanjang. Tetapi ukuran diagonal tidak dituliskan. $\mathrm{S}_{5}$ juga tidak dapat menunjukkan diagonal-diagonal belah ketupat pada gambar. Dari hasil wawancara juga diketahui $\mathrm{S}_{5}$ tidak mampu membedakan sisi dan diagonal dari belah ketupat. Sehingga, dapat disimpulkan $\mathrm{S}_{5}$ dapat menggambar belah ketupat namun tidak paham dalam konsep mengenai diagonal belah ketupat.

3. $2+4=6-6+5=11 \quad 3+2=5$
hasil $=22$
Kurang 3 dari 25

\section{Gambar 5 Hasil pekerjaan $\mathrm{S}_{4}$ soal representasi simbol}

Adapun ringkasan wawancara dengan $\mathrm{S}_{4}$ sebagai berikut.

$\mathrm{S}_{4} \quad$ : "Untuk soal nomor 3 inikan cari $x$ nya. Jadi ditambah $2+4=6,6+5=11,3+2=5$, jadi hasil semua tambahnya itu 22 , kan banyak nya siswa itu 25 saya dapatnya 22 , jadi kurang 3 dari 25. Berarti nilai 6 ada 3 orang"

P : :Lalu berapa siswa yang mendapat nilai dibawah KKM?"

$\mathrm{S}_{4} \quad$ : "Lupa saya jawab Kak"

Berdasarkan hasil wawancara dan jawaban dapat dilihat bahwa $\mathrm{S}_{4}$ kurang memahami soal. $\mathrm{S}_{4}$ telah melakukan perhitungan dengan benar untuk mendapatkan nilai $x$. Namun, langkah-langkah menyelesaikan soal masih kurang lengkap dan kurang sistematis. Sehingga solusi terakhir jumlah siswa yang mendapatkan nilai dibawah KKM tidak dijawab. 
C) Luas beiah Fetupat lebih Panjong Setelah di Perponjang

Gambar 6 Hasil pekerjaan $\mathbf{S}_{6}$ soal representasi verbal

Gambar 6 menunjukkan bahwa $\mathrm{S}_{6}$ tidak dapat menyimpulkan soal yang diberikan. Jawaban yang ditulis tidak logis. Sehingga kesimpulan yang diberikan salah.

Hasil rekapitulasi tes kemampuan representasi matematis siswa ditinjau dari self efficacy seperti pada Tabel 3.

Tabel 3 Persentase Hasil Tes Kemampuan Representasi Matematis pada Tiap Indikator

\begin{tabular}{ccc}
\hline Aspek Representasi Matematis & Self Efficacy Tinggi & Self Efficacy Rendah \\
& & \\
\hline Representasi Gambar & $88,88 \%$ & $61,11 \%$ \\
Representasi Simbol & $97,22 \%$ & $63,88 \%$ \\
Representasi Verbal & $50 \%$ & $30,55 \%$ \\
\hline
\end{tabular}

\subsection{Kemampuan Representasi Matematis Siswa dengan Self Efficacy Tinggi}

Kemampuan representasi matematis siswa yang memiliki self efficacy tinggi untuk indikator menyajikan suatu masalah ke dalam bentuk gambar atau diagram, siswa mampu memahami masalah yang diberikan dan mampu menyajikan masalah ke dalam bentuk gambar atau diagram. Siswa dengan self efficacy tinggi tidak mengalami banyak kesulitan dalam menyelesaikan soal kemampuan representasi gambar. Data atau informasi disajikan dengan tepat ke dalam bentuk gambar atau diagram meskipun ada sedikit kesalahan pada keterangan gambar yang dilukiskan dan mampu dijelaskan saat wawancara dilakukan. Ketercapaian kemampuan representasi gambar pada siswa yang memiliki self efficacy tinggi sebesar $88,88 \%$ dengan kategori sangat baik.

Kemampuan representasi simbol dari self efficacy tinggi untuk indikator menyelesaikan masalah menggunakan persamaan atau model matematika sebesar 97,22\% dengan kategori sangat baik. Siswa dengan self efficacy tinggi dapat memahami soal kemampuan representasi simbol dan menggunakan rumus dengan tepat. Secara keseluruhan siswa dengan self efficacy tinggi mampu menjelaskan langkah-langkah penyelesaian yang digunakan dan proses perhitungan hasil akhir dengan baik. Dalam menuliskan satuan luas yang digunakan, terlihat dari subjek yang memiliki self efficacy tinggi masih terdapat kesalahan dan kurang teliti, namun setelah dilakukan wawancara subjek dengan self efficacy tinggi mampu menyebutkan satuan yang digunakan. Sejalan dengan penelitian yang didapatkan, bahwa dalam indikator menyelesaikan masalah menggunakan persamaan matematis siswa mampu dengan sangat baik menyelesaikan masalah hanya saja masih ada kesalahan pada perolehan hasil dikarenakan kurangnya ketelitian dalam melakukan proses perhitungan (Puranam at.ai,2019). 
Kemampuan representasi verbal dari siswa self efficacy tinggi untuk indikator menggunakan kata-kata tertulis dalam menyelesaikan masalah sebesar 50\% dengan kategori cukup, siswa dengan self efficacy tinggi dapat memahami maksud soal yang diberikan dan menjelaskannya dengan kata-kata yang tersusun logis meskipun kurang lengkap. Dalam menentukan kesimpulan dari soal siswa dengan self efficacy tinggi mampu menjelaskan jawaban secara masuk akal walaupun kurang lengkap. Sebagian besar siswa self efficacy tinggi tidak menuliskan kesimpulan akhir menggunakan katakata namun dapat menjelaskannya saat wawancara. Hal ini sesuai dengan hasil penelitian, bahwa pada indikator representasi verbal siswa dengan self efficacy tinggi dalam menuliskan langkah-langkah penyelesaian dengan kata-kata lebih baik dibandingkan dengan kategori self efficacy lainnya (Nadia at.al,2017).

\subsection{Kemampuan Representasi Matematis Siswa dengan Self Efficacy Rendah}

Kemampuan representasi gambar dari self efficacy rendah, siswa dapat memahami masalah yang diberikan namun kurang mampu menyajikan data atau informasi ke dalam bentuk gambar atau diagram. Siswa dengan self efficacy rendah sebagian besar tidak mampu menunjukkan diagonal pada belah ketupat yang telah digambarkan. Dalam menggambar segi empat, self efficacy rendah sebagian besar dapat menggambar bangun segi empat namun tidak menuliskan keterangan satuan dan ukuran pada gambar sehingga keterangan dari gambar yang disajikan kurang lengkap. Hal tersebut juga diungkapkan dalam hasil penelitian, bahwa siswa dengan self efficacy rendah dalam menjawab soal representasi gambar dapat menggunakan representasi gambar dengan baik meski masih ada beberapa hal yang kurang lengkap (Hijriani at.al, 2018). Ketercapaian kemampuan representasi gambar siswa yang memiliki self efficacy rendah sebesar $61,11 \%$ dengan kategori baik.

Kemampuan representasi simbol dari self efficacy rendah untuk indikator menyelesaikan masalah menggunakan persamaan atau model matematika terlihat bahwa self efficacy rendah dapat memahami soal kemampuan simbol dan menggunakan rumus dengan tepat walaupun sebagian besar menulis jawaban tanpa menuliskan rumus yang digunakan disebabkan kurang teliti. Hal ini sejalan dengan penelitian, bahwa dalam mengerjakan soal yang diberikan dengan menggunakan representasi simbolik menyimpulkan bahwa kurangnya ketelitian yang dimiliki subjek menjadi penyebab ketidakmampuan subjek untuk mengkontruksi representasi simbolik dengan benar(Hijriani at.al, 2019). Siswa yang memiliki self efficacy rendah tidak menuliskan satuan luas yang digunakan namun benar pada hasil akhir perhitungan. Pada materi penyajian data subjek self efficacy rendah mampu memahami masalah dan menyelesaikan soal menggunakan persamaan meskipun kurang sistematis. Ketercapaian kemampuan representasi simbol siswa yang memiliki self efficacy rendah sebesar 63,88\% dengan kategori baik.

Kemampuan representasi verbal dari self efficacy rendah dalam indikator menggunakan kata-kata tertulis dalam menyelesaikan masalah, siswa self efficacy 
rendah secara umum kurang memahami maksud soal yang diberikan dan belum mampu menjelaskannya dengan kata-kata yang tersusun logis. Kurang mampu menjawab dan menjelaskan jawaban secara masuk akal serta kurang lengkap dalam menentukan kesimpulan. Subjek self efficacy rendah dalam menentukan kesimpulan dari diagram, dapat menuliskan kesimpulan dengan benar walaupun kurang maksimal dan kurang lengkap. Hal ini sesuai dengan penelitian yang memperoleh hasil siswa self efficacy rendah belum maksimal dalam indikator representasi matematis terlebih pada saat menyelesaikan persoalan dengan menggunakan kata-kata tertulis, siswa self efficacy rendah belum dapat memaksimalkan pengetahuan sebelumnya (Nadia at.al, 2017). Ketercapaian kemampuan representasi verbal siswa yang memiliki self efficacy rendah sebesar 30,55\% dengan kategori kurang.

\section{SIMPULAN}

Berdasarkan hasil penelitian dan pembahasan, dapat disimpulkan kemampuan representasi matematis siswa dengan self efficacy tinggi dalam aspek representasi gambar mampu dengan sangat baik menyajikan suatu masalah matematika kedalam bentuk gambar atau diagram. Pada aspek representasi simbol, siswa mampu dengan sangat baik menyelesaikan masalah matematika menggunakan persamaan atau model matematika. Dalam representasi verbal, siswa cukup mampu menggunakan kata-kata tertulis dalam menyelesaikan masalah matematika. Sedangkan, siswa dengan self efficacy rendah dalam aspek representasi gambar, mampu dengan baik menyajikan suatu masalah matematika kedalam bentuk gambar atau diagram. Dalam aspek representasi simbol, siswa mampu dengan baik menyelesaikan masalah matematika menggunakan persamaan atau model matematika. Kurang mampu menggunakan katakata tertulis dalam menyelesaikan masalah matematika pada aspek representasi verbal.

\section{REFERENSI}

Arikunto, S. (2018). Dasar-dasar Evaluasi Pendidikan Edisi 3. Jakarta: Bumi Aksara.

Bandura, A. (1997). Self Efficacy: The Exercise of Control. New York: W.H Freeman and Company.

Depdiknas. (2006). Peraturan Menteri Pendidikan Nasional Republik Indonesia Nomor 22 Tahun 2006 Tentang Standar Isi Satuan Pendidikan Dasar dan Menengah. Jakarta: Depdiknas.

Effendi, L. A. (2012). Pembelajaran Matematika dengan Metode Penemuan Terbimbing untuk Meningkatkan Kemampuan Representasi dan Pemecahan Masalah Matematis Siswa SMP. Jurnal Penelitian Pendidikan, Volume 13 Nomor 2, 1-10.

Fadila., Rahayu, W. I., \& Saputra, M. H. (2020). Penerapan Metode Naive Bayes dan Skala Likert pada Aplikasi Prediksi Kelulusan Mahasiswa. Bandung:Kreatif Industri Nusantara.

Hijriani, L., Rahardjo, S., \& Rahardi, R. (2018). Deskripsi Representasi Matematis Siswa SMP dalam Menyelesaikan Soal PISA. Jurnal Pendidikan, Volume 3 Nomor 5, 603-607.

Kurnia, R. D., Mulyani, I., Rohaeti, E. E., \& Fitrianna, A. Y. (2018). Hubungan Antara Kemamdirian Belajar dan Self Efficacy Terhadap Kemampuan Komunikasi 
Matematis Siswa SMK. Jurnal Ilmiah Pendidikan Matematika, Volume 3 Nomor 1, 59-64.

Nadia, L. N., Waluyo, B., \& Isnarto. (2017). Analisis Kemampuan Representasi Matematis Ditinjau dari Self Efficacy Peserta Didik melalui Inductive Discovery Learning. Unnes Journal of Mathematics Education Research, Volume 6 Nomor 2, $242-250$.

NCTM. (2000). Principles and Standards for School Mathematics. Reston: National Council of Teachers of Mathematic.

Purnama, R. N., Kusmaryono, I., \& Basir, M. A. (2019). Analisis Kemampuan Representasi Matematis Siswa Kelas VIII SMP Al Fattah Semarang. Jurnal Pendidikan Didaktik Matematika, Volume 3 Nomor 1, 23-36.

Sabirin, M. (2014). Representasi Dalam Pembelajaran Matematika. Jurnal Pendidikan Matematika IAIN Antasari, Volume 1 Nomor 2, 33-44.

Setyawati, R. D., Ambarizka, E. B., \& Handayanto, A. (2020). Profil Kemampuan Representasi Matematis Siswa SMP Ditinjau dari Self Efficacy. Jurnal Phenomenon, Volume 10 Nomor 2, 220-235.

Siregar, S. (2016). Statistika Deskriptif untuk Penelitian. Jakarta: Raja Grafindo Persada.

Subaidi, A. (2016). Self Efficacy Siswa Dalam Pemecahan Masalah Matematika. Jurnal Sigma, Volume 1 Nomor 2, 64-68.

Villegas, J. L., Castro, E., \& Gutierrez, J. (2009). Representations in Probling Solving: A Case Study in Optimization Problems. Electronic Journal of Research in Educational Psychology, Volume 7 Nomor 17, 279-308. 